\title{
Remodeling Alzheimer-amyloidosis models by seeding
}

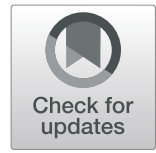

\author{
Brittany S. Ulm, David R. Borchelt and Brenda D. Moore *i]
}

\begin{abstract}
Alzheimer's disease (AD) is among the most prevalent neurodegenerative diseases, with brain pathology defined by extracellular amyloid beta deposits and intracellular tau aggregates. To aid in research efforts to improve understanding of this disease, transgenic murine models have been developed that replicate aspects of AD pathology. Familial AD is associated with mutations in the amyloid precursor protein and in the presenilins (associated with amyloidosis); transgenic amyloid models feature one or more of these mutant genes. Recent advances in seeding methods provide a means to alter the morphology of resultant amyloid deposits and the age that pathology develops. In this review, we discuss the variety of factors that influence the seeding of amyloid beta pathology, including the source of seed, the time interval after seeding, the nature of the transgenic host, and the preparation of the seeding inoculum.
\end{abstract}

Keywords: Alzheimer's disease, Seeding, Amyloid- $\beta$, Mouse models, Prion disease

\section{Background}

Alzheimer's Disease (AD) is pathologically defined by the coexistence of $\beta$-amyloid (A $\beta$ ) deposits and neurofibrillary tangles [1]. Given the role of $\mathrm{A} \beta$ deposition in $\mathrm{AD}$ postmortem diagnosis, generating mouse models that reproduce this pathology by expressing mutant amyloid precursor protein (APP) or presenilin 1 (PS1) has been a substantial focus of research efforts (reviewed in [2]). Mice that express multiple transgenes related to familial $\mathrm{AD}$, mutant APP and PS1, can develop pathology relatively early in life (3-6 months). Conversely, there are models that solely express human APP (wild-type or mutant) that develop amyloid pathology later in life (1218 months) [3]. Seeding has been shown to accelerate the time-course and severity of $A \beta$ deposition in various APP transgenic models, as well as influence the morphology of the ensuing deposits (Tables 1 and S1). These findings in mice parallel early seeding studies that were

\footnotetext{
* Correspondence: brendar@ufl.edu

Department of Neuroscience, Center for Translational Research in Neurodegenerative Disease, McKnight Brain Institute, College of Medicine, University of Florida, Gainesville, FL, USA
}

done in non-human primates, where $A \beta$ deposition was induced (generally after 10ys of age) by seeding from human brain tissue [23-27]. The induced deposits and cerebral angiopathy were detected by immunohistochemistry, Congo red, and silver staining [25, 27]. Seeding has similarly been shown to accelerate pathology caused by the misfolding of tau and $\alpha$-synuclein in mouse models (reviewed in [28-30]). In this review, we focus on the variables at play in manipulating $A \beta$ deposition in APP transgenic mice by seeding.

One of the most notable variables between different $A \beta$ seeding paradigms is the source of the seed, which can be grossly separated into recombinant peptides aggregated in vitro, human donor tissue homogenates, and transgenic mouse model tissue homogenates; each of which have their own nuances that influence the induced pathology. The selection of the host model that has been challenged with $A \beta$ seeds can also factor in the pathological outcomes. Together, these variables conspire to modulate the type of $A \beta$ pathology that is induced by seeding.

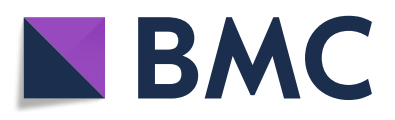

(c) The Author(s). 2021 Open Access This article is licensed under a Creative Commons Attribution 4.0 International License, which permits use, sharing, adaptation, distribution and reproduction in any medium or format, as long as you give appropriate credit to the original author(s) and the source, provide a link to the Creative Commons licence, and indicate if changes were made. The images or other third party material in this article are included in the article's Creative Commons licence, unless indicated otherwise in a credit line to the material. If material is not included in the article's Creative Commons licence and your intended use is not permitted by statutory regulation or exceeds the permitted use, you will need to obtain permission directly from the copyright holder. To view a copy of this licence, visit http://creativecommons.org/licenses/by/4.0/. The Creative Commons Public Domain Dedication waiver (http://creativecommons.org/publicdomain/zero/1.0/) applies to the data made available in this article, unless otherwise stated in a credit line to the data. 
Table 1 Summary of selected $A \beta$ seeding studies

\begin{tabular}{|c|c|c|c|c|c|c|c|}
\hline Reference & $\begin{array}{l}\text { Source of seed } \\
\text { (route of } \\
\text { injection) }\end{array}$ & Host Line & Host Onset & $\begin{array}{l}\text { Host } \\
\text { Pathological } \\
\text { Features }\end{array}$ & $\begin{array}{l}\text { Age Observed } \\
\text { (Age at Time of } \\
\text { Injection) }\end{array}$ & $\begin{array}{l}\text { Pathological } \\
\text { Features of } \\
\text { seed }\end{array}$ & $\begin{array}{l}\text { Pathological Features of } \\
\text { Induced } A \beta \text { Pathology }\end{array}$ \\
\hline [4] & Human (IHC) & $\operatorname{Tg} 2576$ & $\sim 9$ months & $\begin{array}{l}\text { Mixed core > } \\
\text { diffuse }\end{array}$ & 8 months ( 3 months) & $\begin{array}{l}\text { "plaques and } \\
\text { Neurofibrillary } \\
\text { tangles" }\end{array}$ & $\begin{array}{l}\text { Primarily diffuse deposits, } \\
\text { largely } A \beta 42\end{array}$ \\
\hline [5] & Human (IHC) & $\operatorname{Tg} 2576$ & $\sim 9$ months & $\begin{array}{l}\text { Mixed core > } \\
\text { diffuse }\end{array}$ & $\begin{array}{l}8 \text { and } 15 \text { months ( } 3 \\
\text { months) }\end{array}$ & $\begin{array}{l}\text { "plaques and } \\
\text { Neurofibrillary } \\
\text { tangles" }\end{array}$ & $\begin{array}{l}\text { Primarily diffuse in cortex } \\
\text { with some cored deposits in } \\
\text { corpus callosum }\end{array}$ \\
\hline \multirow[t]{7}{*}[6]{} & Human (IHC) & APP23 & 6-9 months & $\begin{array}{l}\text { Mixed core }> \\
\text { diffuse }\end{array}$ & 9 months (5 months) & $\begin{array}{l}\text { "plaques and } \\
\text { neurofibrillary } \\
\text { tangles" }\end{array}$ & $\begin{array}{l}\text { Significant } A \beta \text { deposition that } \\
\text { appeared diffuse }\end{array}$ \\
\hline & $\begin{array}{l}\text { Mouse (APP23) } \\
(\mathrm{IHC})\end{array}$ & & & & $\begin{array}{l}7-9 \text { months ( } 5 \\
\text { months) }\end{array}$ & $\begin{array}{l}\text { Fibrillar, } \\
\text { congophilic, } \\
\text { A } 440>A \beta 42\end{array}$ & $\begin{array}{l}\text { "Diffuse and filamentous". } \\
\text { Some congophilic } \\
\text { parenchymal deposits near } \\
\text { vessels. Dystrophic neurites. }\end{array}$ \\
\hline & $\begin{array}{l}\text { Mouse (APPPS1) } \\
(\mathrm{IHC})\end{array}$ & & & & \multirow[t]{2}{*}{8 months (5 months) } & \multirow{2}{*}{$\begin{array}{l}\text { Fibrillar, } \\
\text { congophilic, } \\
\text { A } 342>A \beta 40\end{array}$} & "course, punctate" \\
\hline & $\begin{array}{l}\text { Synthetic } A \beta \text { and } \\
\text { WT brain extract }\end{array}$ & & & & & & $\begin{array}{l}\text { Limited deposition, similar to } \\
\text { below }\end{array}$ \\
\hline & $\begin{array}{l}\text { Synthetic Aß42 } \\
(100-1000 X)(I H C)\end{array}$ & & & & 9 months (5 months) & $\begin{array}{l}\text { Fibrillar, } \\
\text { congophilic }\end{array}$ & $\begin{array}{l}\text { Some deposits in dentate } \\
\text { gyrus, amorphous mass } \\
\text { (largely injectate) }\end{array}$ \\
\hline & $\begin{array}{l}\text { Mouse (APP23) } \\
(\mathrm{IHC})\end{array}$ & APPPS1 & $3-6$ months & $\begin{array}{l}\text { Mixed core } \\
>>\text { diffuse }\end{array}$ & $\begin{array}{l}3 \text { and } 5 \text { months ( } 2 \\
\text { months) }\end{array}$ & $\begin{array}{l}\text { Fibrillar, } \\
\text { congophilic, } \\
\text { A } 340>A \beta 42\end{array}$ & $\begin{array}{l}\text { "mixture of filamentous and } \\
\text { compact" }\end{array}$ \\
\hline & $\begin{array}{l}\text { Mouse (APPPS1) } \\
(\mathrm{IHC})\end{array}$ & & & & & $A \beta 42>A \beta 40$ & $\begin{array}{l}\text { "course and punctate } \\
\text { deposition" }\end{array}$ \\
\hline [7] & $\begin{array}{l}\text { Mouse (APP23) } \\
\text { (Varied: Olf Bulb, } \\
\text { parietal cortex, } \\
\text { entorhinal cortex, } \\
\text { striatum, IHC) }\end{array}$ & APP23 & 6-9 months & $\begin{array}{l}\text { Mixed core > } \\
\text { diffuse }\end{array}$ & $\begin{array}{l}3 \text { months post } \\
\text { injection ( } 2-5 \\
\text { months, proximal to } \\
\text { injection site), more } \\
\text { robust } 6 \text { months } \\
\text { after injection. }\end{array}$ & $\begin{array}{l}\text { Fibrillar, } \\
\text { congophilic, } \\
\text { A } 340>A \beta 42\end{array}$ & $\begin{array}{l}\text { Parenchymal diffuse A } \beta \text { with } \\
\text { variable congophilic core } \\
\text { plaques and vascular deposits } \\
\text { (see Table S1 for more } \\
\text { details). }\end{array}$ \\
\hline [8] & $\begin{array}{l}\text { Mouse (APP23) } \\
\text { IP injection }\end{array}$ & APP23 & 6-9 months & $\begin{array}{l}\text { Mixed core > } \\
\text { diffuse }\end{array}$ & $\begin{array}{l}\text { 8-9 months ( } 2 \\
\text { months) }\end{array}$ & $\begin{array}{l}\text { Fibrillar, } \\
\text { congophilic, } \\
\text { A } 340>\text { A } \beta 42\end{array}$ & $\begin{array}{l}\text { CAA carrying into nearby } \\
\text { parenchyma. Congophilic } \\
\text { vascular } A \beta \text {, surrounded by } \\
\text { "diffuse, Congo red-negative } \\
\text { A } \beta \text { deposits". }\end{array}$ \\
\hline [9] & $\begin{array}{l}\text { Mouse (APP23) } \\
(\mathrm{IHC})\end{array}$ & $\begin{array}{l}\text { Tg (APP23: } \\
\text { Gfap-luc) }\end{array}$ & 6-9 months & $\begin{array}{l}\text { Mixed core > } \\
\text { diffuse }\end{array}$ & $\begin{array}{l}12 \text { months ( } 2 \\
\text { months) }\end{array}$ & $\begin{array}{l}\text { Fibrillar, } \\
\text { congophilic, } \\
\text { A } \beta 40>A \beta 42\end{array}$ & $\begin{array}{l}\text { "large numbers of small } A \beta \\
\text { plaques ... [and] more diffuse } \\
\text { A } \beta \text { deposits". }\end{array}$ \\
\hline [10] & $\begin{array}{l}\text { Human } \\
(\mathrm{IHC})\end{array}$ & $\begin{array}{l}\text { human WT } \\
\text { APP } \\
\text { Hetero } \\
\text { zygotes } \\
\text { (HuAPPwt) }\end{array}$ & N/A & N/A & $\begin{array}{l}450 \text { days, } 615 \text { days, } \\
750 \text { days ( } 165 \text { days) }\end{array}$ & $\begin{array}{l}\text { "plaques and } \\
\text { Neurofibrillary } \\
\text { tangles" }\end{array}$ & $\begin{array}{l}\text { Diffuse deposits ( } 450 \text { and } 615 \\
\text { days). } 3 / 7 \text { mice ThioS positive } \\
\text { ( } 750 \text { days). }\end{array}$ \\
\hline [11] & $\begin{array}{l}\text { Mouse (APP23, } \\
\text { fractionated } \\
\text { proteinase K } \\
\text { treated) (IHC) }\end{array}$ & APP23 & 6-9 months & $\begin{array}{l}\text { Mixed core > } \\
\text { diffuse }\end{array}$ & $\begin{array}{l}\text { 7-9 months (3-4 } \\
\text { months) }\end{array}$ & $\begin{array}{l}\text { Fibrillar, } \\
\text { congophilic, } \\
\text { A } 340>A \beta 42\end{array}$ & $\begin{array}{l}\text { Mixture diffuse and } \\
\text { congophilic deposits. } \\
\text { A } \beta \text { deposits small and } \\
\text { punctate, some congophilic. }\end{array}$ \\
\hline
\end{tabular}

Mouse (APP23, M

or $\mathrm{F}$, extrasonicated) (IHC)

[12] Mouse (APP23) $(\mathrm{IHC})$

Miffuse

9 months (3 months)

15 months ( 9 months)

Fibrillar, congophilic, $A \beta 40>A B 42$
Largely diffuse deposits in parenchyma and near vessels.

15 months (3 months) 
Table 1 Summary of selected A $\beta$ seeding studies (Continued)

\begin{tabular}{|c|c|c|c|c|c|c|c|}
\hline Reference & $\begin{array}{l}\text { Source of seed } \\
\text { (route of } \\
\text { injection) }\end{array}$ & Host Line & Host Onset & $\begin{array}{l}\text { Host } \\
\text { Pathological } \\
\text { Features }\end{array}$ & $\begin{array}{l}\text { Age Observed } \\
\text { (Age at Time of } \\
\text { Injection) } \\
\end{array}$ & $\begin{array}{l}\text { Pathological } \\
\text { Features of } \\
\text { seed }\end{array}$ & $\begin{array}{l}\text { Pathological Features of } \\
\text { Induced } A \beta \text { Pathology }\end{array}$ \\
\hline \multirow[t]{3}{*}{ [13] } & $\begin{array}{l}\text { Mouse (APP23, } \\
\text { CRND8) (ICV) }\end{array}$ & \multirow[t]{3}{*}{$\begin{array}{l}\text { APP23:Gfap- } \\
\text { luc }\end{array}$} & \multirow[t]{3}{*}{ 6-9 months } & \multirow[t]{3}{*}{$\begin{array}{l}\text { Mixed core > } \\
\text { diffuse }\end{array}$} & \multirow[t]{3}{*}{$\begin{array}{l}\text { 330-385 days post } \\
\text { injection ( } 2 \text { months) }\end{array}$} & $\begin{array}{l}\text { Fibrillar, } \\
\text { congophilic }\end{array}$ & $\begin{array}{l}\text { Increased A } A \text { deposition; } \\
\text { morphology not described. }\end{array}$ \\
\hline & $\begin{array}{l}\text { Brain purified } \\
\text { fibrils (ICV) }\end{array}$ & & & & & $\begin{array}{l}\text { Fibrils. } \\
\text { 15-20x more } \\
\text { A -rich than } \\
\text { non-purified }\end{array}$ & $\begin{array}{l}\text { Increased A } \beta \text { deposition; } \\
\text { morphology resembles cored } \\
\text { plaques. }\end{array}$ \\
\hline & $\begin{array}{l}\text { Synthetic WT } \\
\text { A } 40 \text { (ICV) } \\
\text { Synthetic S26C } \\
\text { A } 40 \text { (ICV) }\end{array}$ & & & & & $\begin{array}{l}\text { Fibrillar, } \\
\text { congophilic }\end{array}$ & $\begin{array}{l}\text { Increased } A \beta \text {; morphology } \\
\text { resembles cored plaques in } \\
\text { corpus callosum. }\end{array}$ \\
\hline \multirow[t]{4}{*}[6,14,15]{} & $\begin{array}{l}\text { Mouse (APP23) } \\
(\mathrm{IHC})\end{array}$ & \multirow[t]{2}{*}{ APP23 } & \multirow[t]{2}{*}{$6-9$ months } & \multirow[t]{2}{*}{$\begin{array}{l}\text { Mixed core > } \\
\text { diffuse }\end{array}$} & \multirow[t]{2}{*}{$\begin{array}{l}7-9 \text { months (4-6 } \\
\text { months) }\end{array}$} & $\begin{array}{l}\text { Fibrillar, } \\
\text { congophilic, } \\
\text { A } 340>A \beta 42\end{array}$ & \multirow{4}{*}{$\begin{array}{l}\text { Diffuse deposits in molecular } \\
\text { layer of dentate gyrus that } \\
\text { exhibit spectral properties of } \\
\text { seed source when stained } \\
\text { with trimeric polythiophene } \\
\text { acetic acid }\end{array}$} \\
\hline & $\begin{array}{l}\text { Mouse (APPPS1) } \\
(\mathrm{IHC})\end{array}$ & & & & & $\begin{array}{l}\text { Fibrillar, } \\
\text { congophilic, } \\
\text { A } 342>A \beta 40\end{array}$ & \\
\hline & $\begin{array}{l}\text { Mouse (APP23) } \\
(\mathrm{IHC})\end{array}$ & APPPS1 mice & $3-6$ months & $\begin{array}{l}\text { Mixed core } \\
>>\text { diffuse }\end{array}$ & $\begin{array}{l}3-4 \text { months (1.5-2 } \\
\text { months) and } 6 \\
\text { months ( } 3 \text { months) }\end{array}$ & $\begin{array}{l}\text { Fibrillar, } \\
\text { congophilic, } \\
\text { A } 340>A \beta 42\end{array}$ & \\
\hline & $\begin{array}{l}\text { Mouse (APPPS1) } \\
(\mathrm{IHC})\end{array}$ & & & & & $\begin{array}{l}\text { Fibrillar, } \\
\text { congophilic, } \\
\text { A } 342>A \beta 40\end{array}$ & \\
\hline \multirow[t]{4}{*}{ [16] } & $\begin{array}{l}\text { Synthetic Aß40 } \\
\text { (NaP) } \\
(\mathrm{ICV})\end{array}$ & $\begin{array}{l}\text { APP23:Gfap- } \\
\text { luc }\end{array}$ & 6-9 months & $\begin{array}{l}\text { Mixed core > } \\
\text { diffuse }\end{array}$ & $\begin{array}{l}330 \text { days after } \\
\text { injection ( } 6-8 \text { weeks) }\end{array}$ & $\begin{array}{l}\text { (long straight } \\
\text { fibrils, rarely } \\
\text { short fibrils) }\end{array}$ & \multirow[t]{4}{*}{$\begin{array}{l}\text { Mixed ThioS-positive compact } \\
\text { deposits with dense Thio-S } \\
\text { negative deposits. }\end{array}$} \\
\hline & $\begin{array}{l}\text { Synthetic Aß42 } \\
\text { (NaP) } \\
\text { (ICV) }\end{array}$ & & & & & $\begin{array}{l}\text { (long fibrils, } \\
\text { mostly short } \\
\text { fibrils) }\end{array}$ & \\
\hline & $\begin{array}{l}\text { Synthetic Aß40 } \\
\text { (NaP/SDS) }\end{array}$ & & & & & $\begin{array}{l}\text { (long straight } \\
\text { fibrils) }\end{array}$ & \\
\hline & $\begin{array}{l}\text { Synthetic A } 442 \\
\text { (NaP/SDS) }\end{array}$ & & & & & $\begin{array}{l}\text { (long fibrils } \\
\text { with some } \\
\text { twists) }\end{array}$ & \\
\hline \multirow[t]{3}{*}{ [17] } & $\begin{array}{l}\text { Mouse (APP23/ } \\
\text { APPPS1) } \\
\text { (IP injection) }\end{array}$ & APP23 & 6-9 months & $\begin{array}{l}\text { Mixed core }> \\
\text { diffuse }\end{array}$ & $\begin{array}{l}7-8 \text { months ( } 1-2 \\
\text { months), more } \\
\text { robust } 7-8 \text { months } \\
\text { after injection }\end{array}$ & $\begin{array}{l}\text { Fibrillar, } \\
\text { congophilic, }\end{array}$ & $\begin{array}{l}\text { Diffuse parenchymal, variable } \\
\text { vascular deposition. 5-15\% } \\
\text { deposits congophilic. }\end{array}$ \\
\hline & $\begin{array}{l}\text { Mouse (APP23/ } \\
\text { APPPS1) } \\
\text { (IP injection) }\end{array}$ & $\begin{array}{l}\text { homozygous } \\
\text { R1.40 }\end{array}$ & 10-14 months & $\begin{array}{l}\text { Mixed core }> \\
\text { diffuse }\end{array}$ & $\begin{array}{l}\text { Somewhat at 9-10 } \\
\text { months (1-2 } \\
\text { months), more } \\
\text { robust } 10-12 \\
\text { months after } \\
\text { injection. }\end{array}$ & $\begin{array}{l}\text { Fibrillar, } \\
\text { congophilic, }\end{array}$ & $\begin{array}{l}\text { Deposits of neocortex in } \\
\text { younger groups largely } \\
\text { vascular, but in older groups } \\
\text { more parenchymal diffuse } \\
\text { plaques. }\end{array}$ \\
\hline & $\begin{array}{l}\text { Mouse (APP23/ } \\
\text { APPPS1) } \\
\text { (IP injection) }\end{array}$ & $\begin{array}{l}\text { hemizygous } \\
\text { APP23 with } \\
\text { murine APP } \\
-/-\end{array}$ & 9-10 months & & $\begin{array}{l}\text { 9-10 months (1-2 } \\
\text { months) }\end{array}$ & $\begin{array}{l}\text { Fibrillar, } \\
\text { congophilic, }\end{array}$ & $\begin{array}{l}\text { Diffuse parenchymal, vascular } \\
\text { deposits evidence with } 5 \% \\
\text { congophilic. }\end{array}$ \\
\hline \multirow[t]{3}{*}{ [18] } & $\begin{array}{l}\text { Human (fixed) } \\
(\mathrm{IHC})\end{array}$ & \multirow[t]{3}{*}{ APP23 } & \multirow[t]{3}{*}{ 6-9 months } & \multirow[t]{3}{*}{$\begin{array}{l}\text { Mixed core > } \\
\text { diffuse }\end{array}$} & \multirow[t]{3}{*}{$\begin{array}{l}7-8 \text { months (3-4 } \\
\text { months) }\end{array}$} & $\begin{array}{l}\text { "plaques and } \\
\text { neurofibrillary } \\
\text { tangles" }\end{array}$ & \multirow{3}{*}{$\begin{array}{l}\text { Small, compact, punctate A } \beta \\
\text { deposits. Thioflavin-S and } \\
\text { Congo Red staining not } \\
\text { reported. }\end{array}$} \\
\hline & $\begin{array}{l}\text { Mouse (APPPS1, } \\
\text { fresh frozen) } \\
(\mathrm{IHC})\end{array}$ & & & & & \multirow[t]{2}{*}{$\begin{array}{l}\text { Fibrillar, } \\
\text { congophilic, }\end{array}$} & \\
\hline & $\begin{array}{l}\text { Mouse (APPPS1, } \\
\text { fixed and } \\
\text { cryoprotected) } \\
(\mathrm{IHC})\end{array}$ & & & & & & \\
\hline
\end{tabular}


Table 1 Summary of selected A $\beta$ seeding studies (Continued)

\begin{tabular}{|c|c|c|c|c|c|c|c|}
\hline Reference & $\begin{array}{l}\text { Source of seed } \\
\text { (route of } \\
\text { injection) }\end{array}$ & Host Line & Host Onset & $\begin{array}{l}\text { Host } \\
\text { Pathological } \\
\text { Features }\end{array}$ & $\begin{array}{l}\text { Age Observed } \\
\text { (Age at Time of } \\
\text { Injection) } \\
\end{array}$ & $\begin{array}{l}\text { Pathological } \\
\text { Features of } \\
\text { seed }\end{array}$ & $\begin{array}{l}\text { Pathological Features of } \\
\text { Induced } A \beta \text { Pathology }\end{array}$ \\
\hline & $\begin{array}{l}\text { Mouse (APP23, } \\
\text { fresh frozen) } \\
(I \mathrm{HC})\end{array}$ & & & & & & \\
\hline & $\begin{array}{l}\text { Mouse (APP23, } \\
\text { fixed and } \\
\text { cryoprotected) } \\
(\mathrm{IHC})\end{array}$ & & & & & & \\
\hline \multirow[t]{2}{*}{ [19] } & $\begin{array}{l}\text { Human (fresh } \\
\text { frozen } \\
\text { supernatant from } \\
\text { formic acid- } \\
\text { soluble fraction) } \\
(\mathrm{IHC})\end{array}$ & APP23 & 6-9 months & $\begin{array}{l}\text { Mixed core > } \\
\text { diffuse }\end{array}$ & $\begin{array}{l}12 \text { months (4 } \\
\text { months) }\end{array}$ & $\begin{array}{l}\text { "plaques and } \\
\text { Neurofibrillary } \\
\text { tangles" }\end{array}$ & Diffuse $A \beta$ depositions. \\
\hline & $\begin{array}{l}\text { Human } \\
\text { (supernatant } \\
\text { mixed with CSF) } \\
(\mathrm{IHC})\end{array}$ & & & & $\begin{array}{l}10-11 \text { months ( } 3-4 \\
\text { months) }\end{array}$ & $\begin{array}{l}\text { "plaques and } \\
\text { Neurofibrillary } \\
\text { tangles" }\end{array}$ & $\begin{array}{l}\text { Robust } A \beta \text { deposition, largely } \\
\text { diffuse. }\end{array}$ \\
\hline [20] & $\begin{array}{l}\text { Mouse (APP23 } \\
\text { mouse } \\
\text { hippocampi } \\
\text { seeded } 1 \text { and } 30 \\
\text { days prior with } \\
\text { APP23 brain } \\
\text { tissue) }\end{array}$ & $\begin{array}{l}\text { APP23 mice } \\
\text { (male) }\end{array}$ & & & $\begin{array}{l}7 \text { and } 11 \text { months ( } 3 \\
\text { months) }\end{array}$ & & $\begin{array}{l}\text { Some congophilic deposits, } \\
\text { both parenchymal and } \\
\text { vascular. }\end{array}$ \\
\hline \multirow[t]{2}{*}{ [21] } & $\begin{array}{l}\text { Mouse (APP23) } \\
(\mathrm{IHC})\end{array}$ & APP23 mice & $6-9$ months & $\begin{array}{l}\text { Mixed } \\
\text { core }>\text { diffuse }\end{array}$ & $\begin{array}{l}\text { Robust at 9-10 } \\
\text { months (3-4 } \\
\text { months) }\end{array}$ & $\begin{array}{l}\text { Fibrillar, } \\
\text { congophilic, } \\
A \beta 40>A \beta 42\end{array}$ & $\begin{array}{l}\text { "Diffuse and filamentous" A } \beta \\
\text { deposition. }\end{array}$ \\
\hline & $\begin{array}{l}\text { Mouse (APPPS1) } \\
(\mathrm{IHC})\end{array}$ & & & & $\begin{array}{l}\text { Robust at 9-10 } \\
\text { months (3-4 } \\
\text { months) }\end{array}$ & $\begin{array}{l}\text { Fibrillar, } \\
\text { congophilic, } \\
\text { A } 342>A \beta 40\end{array}$ & $\begin{array}{l}\text { "Punctate and compact" A } \\
\text { deposition }\end{array}$ \\
\hline \multirow[t]{2}{*}{ [22] } & $\begin{array}{l}\text { Mouse (5xFAD) } \\
(\mathrm{IHC})\end{array}$ & $5 x F A D$ & $\begin{array}{l}\sim 4 \text { months } \\
\text { (hippocampus) }\end{array}$ & $\begin{array}{l}\text { Mixed core } \\
>>\text { diffuse }\end{array}$ & $\begin{array}{l}13 \text { weeks initial } \\
\text { plaques observed; } \\
\text { also } 4 \text { months ( } 7 \\
\text { weeks) }\end{array}$ & $\begin{array}{l}\text { Fibrillar, } \\
\text { congophilic, } \\
\text { A } 342>A \beta 40\end{array}$ & $\begin{array}{l}\text { Punctate and compact } \\
\text { deposits in hippocampus and } \\
\text { dentate gyrus }\end{array}$ \\
\hline & $\begin{array}{l}\text { Mouse (APP23) } \\
(\mathrm{IHC})\end{array}$ & APP23 & $6-9$ months & & 9 months (6 months) & $\begin{array}{l}\text { Fibrillar, } \\
\text { congophilic, } \\
A \beta 40>A \beta 42\end{array}$ & \\
\hline
\end{tabular}

The intracerebral injection of tissue homogenates or purified $A \beta$ seeds would be expected to induce gliosis that could also influence amyloid seeding. The induction of gliosis alone does not seem to be sufficient to induce $\mathrm{A} \beta$ deposition as injection of human brain lysates from aged individuals with small amounts of $A \beta$ pathology results in little to no seeding [6]. Additionally, previous work by Chakrabarty et al., has shown that when gliosis is chronically activated in the brains of APP transgenic mice by overexpression of the cytokine IL-6, A $\beta$ deposition is attenuated [31]. Further, environmental enrichment of the $5 x F A D$ mice resulted in increased levels of activated microglia and a concomitant reduction of $A \beta$ seeding [22]. Together these results indicate that any inflammation that arises in these models from injection of $A \beta$ seed preparations could diminish seeding efficacy. However, the overwhelming evidence from published studies indicate that if inflammation is induced by the injection of seeds, then the activity of the injected $A \beta$ seeds is sufficient to overwhelm any negative effects of inflammation that may have been induced.

One of the most consistent hallmarks of $A \beta$ seeding is the acceleration of pathology. Bilateral hippocampal (and overlying neocortical) injection of 5-month-old APP23 mice with brain homogenates from aged APP23 mice results in hippocampal seeding of $\mathrm{A} \beta$ deposition 1 month earlier than uninjected mice [6]. Accelerated deposition in APP23 mice is also observed when the seeding homogenate is derived from other murine amyloiddepositing models such as APPPS1 mice [6]. Similarly, young APPPS1 mice injected with brain extracts from older APP23, or APPPS1, mice show earlier onset of amyloidosis [6]. This acceleration of pathology may be appreciable only near the site of seed injection, as described in APP23 mice that received intrahippocampal injections at 4-6 months of age to then develop 
pathology at 7-9 months of age [14]. Notably, in this paradigm other regions of the brain may already be showing pathology by the age of analysis, indicating that injected seeds are introduced into a CNS with elevated levels of total $\mathrm{A} \beta$ burden.

The role that aging plays in mediating the severity of seeded $A \beta$ pathology has been difficult to address because nearly all of the studies have used mice that will eventually develop $A \beta$ pathology. In a study in the R1.40 APP transgenic mice that do not develop pathology until 15 months of age, injection of seeds at 3 or 9 months produced the same levels of pathology at 6 months postinjection [12]. Aging the mice for 12 months after seeding resulted in a widespread distribution of amyloid pathology throughout the forebrain, with congophilic plaques proximal to the injection site [12]. Collectively, these findings indicate that severity and onset of $A \beta$ pathology in APP transgenic mice can be effectively accelerated by injecting young animals with brain extracts from older mice with high levels of $A \beta$ pathology.

\section{Seeds derived from aged APP transgenic mice}

One of the benefits of using seeds prepared from existing transgenic mouse models is the ability to select for a vast range of variables, including genotype, age, sex, and fixation methods, in addition to other post-harvest processing methods. Additionally, humans with AD display a spectrum of $A \beta$ pathologies ranging from diffuse, to vascular, to cored neuritic deposits [32]. Although many mouse models show a similar spectrum of pathology, a subset of models that have been described show a preponderance of one type of $A \beta$ pathology over another [33]. For example, the APPswe/PS1dE9 models of amyloidosis are prone to develop cored neuritic $A \beta$ deposits early [33, 34]. Mice that express a mutant murine APP develop $A \beta$ deposits that are primarily diffuse [33]. Thus, it may be possible to manipulate the type of $A \beta$ pathology that is seeded by selection of the donor source of seed.

\section{Donor and host genetics}

The characteristics of the host transgenic mouse strain can be an influential factor in the development of downstream pathology, with different lines of APP transgenic mice responding to seeding by producing $A \beta$ deposits with distinct morphologies and localizations. Autologous seeding may or may not maintain the expected pathology of the models used; for example, APP23 mice injected with APP23 extract from older mice develop primarily diffuse plaques instead of the expected dense core deposits of this model $[6,15]$ (Tables 1 and S1). APPPS1 seeds injected into APPPS1 mice develop many compact, punctate plaques that are typical of this model $[6,14]$. Injecting APPPS1 mice with APP23 seeds results in a mixture of pathology; diffuse, filamentous $A \beta$ as well as compact plaques $[6,14]$. Conversely, APPPS1 mice injected with APP23 homogenate develop plaques that are more diffuse than the highly punctate deposits seen in APPPS1 mice injected with APPPS1 homogenate [6, 14]. Localization of seeded deposits is also influenced by the transgenic mouse strain of the donor seed, with APP23- and APPPS1-derived seeds resulting in distinct patterns of plaque localization in the dentate gyrus [14]. Collectively, these findings are consistent with the proposed idea that different pathological morphologies of $\mathrm{A} \beta$ deposition are manifestations of a strain-like behavior of the misfolded $A \beta$ that produces these pathologies [35].

To date, it has not been possible to seed pathology in non-transgenic host mice by injecting murine-derived seeds of human $A \beta[4,6,20,22]$. In addition, the injection of non-transgenic brain homogenate has not demonstrated efficacy in seeding either transgenic or nontransgenic hosts $[6-8,11,12,17,18,22]$. Combining non-transgenic brain homogenate with synthetic $A \beta$ results in limited seeding of A $\beta$ deposition in APP23 mice, but not in non-transgenic mice [6,11]. These findings indicate that endogenous mouse $A \beta$ is difficult to seed. Overproduction of mouse $A \beta$ by mutant murine APP transgenes produces $A \beta$ deposits that are similar to pathology produced by human $A \beta$ [36], suggesting that mouse $A \beta$ is not inherently resistant to aggregation. The inability to seed non-transgenic mice may be a consequence of the way in which endogenous WT APP is processed by BACE1 to favor the production of $A \beta 11-$ 40 and $A \beta 11-42$ over $A \beta 1-40$ and $A \beta 1-42$ [37, 38]. Hence, in non-transgenic mice the level of $A \beta 1-42$ may be too low to sustain amyloid deposition even after seeding.

APP processing can lead to a variety of $A \beta$ peptide lengths, which are thought to influence the development of amyloid plaque formation; the main form produced is $\mathrm{A} \beta 40$, while $\mathrm{A} \beta 42$ (produced at lower levels) is considered pathogenic (reviewed in [39]). Biochemical studies have shown that $A \beta 42$ can form fibrils and aggregates much more rapidly than $A \beta 40$ [40]. To understand the role of these peptides in amyloid pathology, mouse strains with differing levels of each peptide have been developed. These transgenic mouse strains reveal that the levels and ratios of $A \beta 40 / A \beta 42$, both in the donor and the host, affect the resultant $A \beta$ peptides composition [14]. Through the seeding of $A \beta$ pathology, augmentation of both peptide lengths can be observed; for example, APP23:Gfap-luc mice seeded with APP23 homogenate exhibit increases in both $A \beta 40$ and $A \beta 42$ levels $[6,9]$. Injection of seeds from APPPS1 mice, with low $A \beta 40: A \beta 42$ ratios can lower the $A \beta 40: A \beta 42$ ratio in APP23 mice, suggesting that seeded deposits may 
selectively incorporate specific A $\beta$ peptides [14]. However, injection of seeds from APP23 mice into APPPS1 mice does not significantly alter the $A \beta 40: A \beta 42$ ratio, most likely because the host $A \beta 42$ aggregates so rapidly [14]. The most consistent finding is that in APP models that produce both $A \beta 40$ and $A \beta 42$, the deposition of both peptides appears to be induced by seeding.

\section{Concentration}

Another variable that has a clear influence on the development of downstream $A \beta$ deposition is the concentration of $A \beta$ in the seed preparation. Reports of concentrations of $A \beta$ in seeding inoculum are variable;

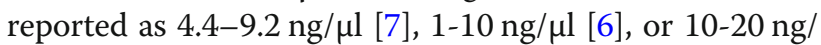
$\mu \mathrm{l}[8,12,14,17]$. The severity of deposition in seeded APP-transgenic mice generally corresponds to the severity of pathology in the brains used for seeding preparation. In one study of seeding activity across different ages, total seeding activity peaked at the initial stage of deposition (in the donor mice), corresponding to a momentary spike in the $A \beta 42: 40$ ratio [21]. Still, seeding homogenates prepared from young APP transgenic donors show lower efficacy due to lower levels of $A \beta$ in the seed preparations $[6,21]$. Lowering $A \beta$ concentration in homogenates by immunodepletion predictably attenuates seeding efficiency of the homogenate even when intracerebrally injected $[6,17]$. The importance of concentration on seeding efficacy is also evident in peripheral application via intraperitoneal injection, which similarly does not exhibit a 1:1 change in pathology to concentration correlation [17]. Importantly, in models in which investigators have injected seeds peripherally, the levels of transgene expression in APP host mice influences the efficacy of pathology induction [17]. Not surprisingly, the higher the level of expression in the host, the better the efficacy of seeding after peripheral injection.

\section{Seed preparation and inactivation by treatment}

For murine-derived seeds, there are a variety of preparation methods that influence seeding efficacy, such as homogenate preparation via homogenization of wholeor forebrain tissue in PBS $(10 \% \mathrm{w} / \mathrm{v})$ followed by sonication and centrifugation to obtain a supernatant fraction $[6,7,22]$. Extracts may be further diluted in buffer containing bovine serum albumin before injection [9]. Treatments of homogenates that degrade or disrupt the amyloid aggregates diminish seeding efficacy; for example, heating and formic acid treatment attenuate the seeding capacity and terminate seeding ability, respectively [6]. Two methods meant to degrade $A \beta$ aggregates from brain lysates to smaller $A \beta$ assemblies, proteinase $K$ treatment and extended sonication, resulted in slight attenuation and increased amyloid seeding, respectively, with distinct plaque morphology [11]. Proteinase K treated lysates seeded large, congophilic aggregates while longer sonication times resulted in smaller and more punctate amyloid deposits. The treatment of APP23 mouse brain homogenate with proteinase $\mathrm{K}$ and subsequent heat inactivation yields seeded mice with lower levels of deposition than that of mice seeded with untreated homogenate; the resulting deposits were primarily diffuse, with a subset of deposits identified as congophilic structures characteristically surrounded by neuritic pathology and gliosis [11]. The murine brain tissue can also be fractionated, with the injection of supernatant and pellet portions of fractionated APP23 homogenate producing 30 and $95 \%$ of the level of $A \beta$ deposition, respectively, that was observed by crude homogenates [11]. The level of deposition caused by injection of the supernatant was unexpected given the low levels of $A \beta$ that were present in that fraction [11]. Interestingly, the soluble $A \beta$ seeds were much more sensitive to proteinase $K$ treatment [11]. Increasing the degree of sonication of the $A \beta$-containing homogenate increases the efficacy of seeding $A \beta$ deposition, while also altering the plaque morphology to smaller punctate deposits [11]. Another aspect of seed preparation is whether the tissue is fresh frozen or formaldehyde-fixed. While formaldehyde-fixed brain homogenate can induce $A \beta$ plaque deposition, the resultant morphology can be changed, such as in the case of APP23 homogenate resulting in diffuse plaques when prepared from frozen tissue, with more punctate deposits resulting when seeds were prepared from fixed tissue [18]. Surprisingly, tissue homogenates dried onto stainless steel wire (implanted into APP23 mice) has been found to seed plaques [7]. Together, these findings indicate that $A \beta$ seeds are relatively stable, can resist inactivating treatments, and can potentially be transmitted on metal surfaces.

\section{Location of injection}

The route of administration of $A \beta$ seed has an effect on the resulting amyloid deposition. Intracerebral injections of murine $A \beta$ seeds are largely focused on the hippocampus, often also spreading to the overlying cortex $[6$, $7,9,11,12,14,18-22]$. However, the precise stereotactic location of injections can be altered, resulting in distinct patterns of seeded pathology progression [7]. Injection of $A \beta$ seeds into the olfactory bulb, parietal cortex, entorhinal cortex, striatum, and hippocampus resulted in accelerated seeded pathology that resembled the host animal [7]. Plaque morphology can also be affected by injection location, with striatal injections resulting in more diffuse plaques than in brains injected at other locations (e.g. hippocampus) [7]. Certain aspects of pathology appear to be maintained despite injection location, such as congophilic vascular deposition in APP23 mice 
seeded by intracerebral injection of APP23 homogenates [7].

Intraperitoneal injection of murine (APP23) brainderived seed results in seeded deposits which can be both vascular and parenchymal in nature $[8,17]$. Additional pathology associated with this intraperitoneal seeding includes glial activation and tau hyperphosphorylation [8]. However, the speed at which intraperitoneal injection of $A \beta$ seed induces pathology is slower than that of intracerebral injection [8]. Intraperitoneal injection, while peripheral, maintains seeding capability in mice that do not express APP peripherally [17]. While intraperitoneal injection can initially result in detectable $\mathrm{A} \beta$ in monocytes, liver, and spleen, peripheral deposits are not induced in the long term [17]. Collectively, these studies suggest that the environment in which seeds are introduced may influence the type of $A \beta$ pathology that ultimately develops.

\section{Morphology of seeded pathology}

There are a variety of amyloid plaque-related morphological features observed in $A \beta$ seeded mice that emulate different aspects of Alzheimer's pathology. Seeded amyloid deposit morphology is influenced by the donor seed; deposits can be either diffuse, compact, or a combination thereof $[6,9,11,12,14,17,18,21]$. The induction of $A \beta$ deposition can be associated with astrocytic activation as observed by increased GFAP immunoreactivity $[9,13]$. At variable levels, seeded deposits have been reported to stain positive with Congo red $[6,7,11,12,17$, 20]. These congophilic deposits can be associated with the vasculature or appear in the parenchyma with glial activation and neuritic pathology $[6,7,11,20]$. The range of reported pathology includes thalamic cerebral amyloid angiopathy $[9,20]$. In the intraperitoneal injection of $A \beta$ seeds, it was observed that large seeded plaques accrue neighboring smaller plaques to a greater degree than would be expected for the host model [17]. These findings clearly indicate the potential to use seeding to direct the type of $A \beta$ pathology that a given APP model may produce; however, in most cases reported, the induction of cored, Thioflavin/Congo red positive deposits is more variable than induction of diffuse $A \beta$ deposits (Tables 1 and S1).

\section{Seeds derived from aged human brain}

The utilization of $A \beta$ seeds from human donors demonstrates a clear avenue whereby amyloid deposition that emulates human pathology could be enhanced. While the variability associated with the utilization of human donor samples is a logical detriment, the ability of human tissue to induce amyloid pathology in APP transgenic mice is clear.

\section{Donor factors}

Human donor-derived $A \beta$ seeding is performed with brain tissue from decedents with diagnosed AD that has been confirmed histologically post mortem. Similar to what is observed in mouse to mouse seeding, human to mouse seeding results in $A \beta$ accumulation at an accelerated time point $[4-6,18,19]$. Homogenates from agematched human samples that are cognitively normal, but positive for $\mathrm{A} \beta$ (likely related to accumulation during aging), also demonstrate seeding capability, though to a notably lesser extent than the $A \beta$-rich seeds derived from AD-diagnosed donors, $10-15 \%[4,6]$. Brain homogenates from age-matched controls negative for $A \beta$ deposits, in addition to $A \beta$-negative young controls, are not found to induce $A \beta$ deposition $[4,10,18]$. Seeding of transgenic APP mice that do not develop amyloid plaques (HuAPPwt) has also been demonstrated using human amyloid-positive donor brain tissue [10]. By contrast, cerebral spinal fluid from $\mathrm{AD}$ patients does not demonstrate efficient seeding activity [19].

\section{Seed preparation}

Differential processing of the seeding tissue can be used to attain seeded pathology in vivo. Supernatant fractions from fresh or frozen human AD-diagnosed donor brain homogenate, similar to mouse seed preparation, are commonly used to induce $A \beta$ deposition in transgenic APP-expressing mice $[4-6,10]$. In addition to samples that are attained via sonication and centrifugation, tissue can be further processed to yield the formic acid-soluble fraction, which seeds diffuse deposits [19]. Formaldehyde-fixed human AD-diagnosed donor brainderived seeds result in hippocampal $A \beta$ deposits upon intrahippocampal injection [18]. The seeding of $A \beta$ deposition by hippocampal injection of CSF (whether from $\mathrm{AD}$-diagnosed patients or age-matched human controls), even when concentrated, does not result in $A \beta$ deposition in APP23 mice [19].

\section{Acceleration of pathology}

As observed in the murine-induced seeding of $A \beta$ pathology, seeding with human $\mathrm{AD}$ brain homogenates can have a profound influence on level of downstream amyloid accumulation. For example, unilateral intrahippocampal injections of $\mathrm{AD}$ brain homogenates into 3 month old $\mathrm{Tg} 2576$ mice produced pathology preferential to the injected hemisphere by 8 months of age $[4,5]$. In initial reports of this model, pathology was primarily found along the hippocampal fissure and around hippocampal blood vessels [4]. Subsequent studies in which $\operatorname{Tg} 2576$ mice that were seeded by human AD brain were aged for 12 months reported exacerbation of cortical $A \beta$ pathology [5]. A striking example of induced pathology by human $\mathrm{AD}$ brain homogenates used heterozygous 
WT human APP mice, which do not develop amyloid deposits [41]. Injection of brain homogenate from a human AD donor into 165 day old WT-APP mice induced A $\beta$ deposits by 285 days post-inoculation [10]. Seeded mice also demonstrated increases in GFAP-positive staining (particularly in the cortex) and some mice developed Thioflavin-S (ThioS) positive aggregates [10]. This study is a clear example in which seeding can be used to generate novel models of AD amyloidosis.

\section{Morphology of seeded pathology}

The morphology of $A \beta$ deposits induced by human donor brain tissue can vary, with a range of important features found. Most aged AD tissue contains numerous diffuse and ThioS positive compact deposits [42]. However, mice seeded with human $\mathrm{AD}$ brain homogenates often develop diffuse $A \beta$ pathology, with relatively few ThioS or congophilic compact deposits formed $[4,5,10$, 19]. Human seeding into mouse can produce deposits that favor one $A \beta$ length over another, with some more immunoreactive for $A \beta 42$ than for $A \beta 40$, despite the fact that the host endogenous deposits normally contain both $A \beta$ peptides [4]. A subset of the $A \beta$ pathology includes congophilic deposits, though these may favor $A \beta 40$ aggregation [4]. Overall, similar to studies in which homogenates prepared from mice are used in seeding, the $A \beta$ pathology induced by human seeds is often described as diffuse (Table 1 and $\mathrm{S} 1$ ).

\section{Seeding with synthetic $A \beta$ peptides}

Similar to seeding with brain extracts, injection of aggregates of synthetic $A \beta$ can produce an acceleration in $A \beta$ pathology in APP transgenic recipients $[13,16]$. Synthetic $A \beta$ was initially ineffective in seeding amyloid deposition in APP23 mice, even when concentrations were raised 100- to 1000-fold relative to tissue homogenates [6]. Since these initial findings, further studies have demonstrated that bilateral pathology can develop from unilateral injection of high levels of synthetic $A \beta$ seeds, suggesting that pathologically misfolded $A \beta$ can propagate from one hemisphere to the other [13]. Other studies have found that small assemblies of synthetic $A \beta$, such as protofibrils, and other structures are capable of seeding amyloid deposition in APP transgenic mice [43]. As with other types of $A \beta$ seeds, an array of variables can influence the resultant pathology.

\section{Seed properties and preparation}

In brain homogenate studies, the $\mathrm{A} \beta 40$ and $\mathrm{A} \beta 42$ content results largely from the genotype and preparation of brain homogenate; in the case of synthetic $A \beta$ seed preparation, the amount of one form versus the other can be controlled. In vitro, synthetic $A \beta 40$ forms longer, straighter fibrils than synthetic Aß42 [16]. The composition of synthetic $A \beta$ seeds has a large effect on the ensuing plaque pathology, with preparation playing a notable role in this outcome. For example, SDStreatment of synthetic $A \beta 42$ alters the resultant plaque morphology from numerous, small plaques with more $A \beta 42$ than $A \beta 40$, to larger, less plentiful plaques with an $A \beta 40: A \beta 42$ ratio more similar to endogenous APP23 mice (similar in appearance to $A \beta 40$ with and without SDS-treatment) [16]. The deposition of $A \beta$ in these synthetic models is largely along the corpus callosum, with an emphasis on the region neighboring the CA1 in mice injected with synthetic A $\beta 40$ (SDS-naïve) [16]. Seeding with a synthetic dodecamer, termed $A \beta 42$ large fatty acid-derived oligomers, can selectively induce acute cerebral amyloid angiopathy when injected in newborn CRND8 mice [44]. Importantly, seeds prepared from human $\mathrm{AD}$ brain can be used to seed synthetic $\mathrm{A} \beta$ peptides in vitro [45], and it may be possible to use this method to amplify specific strains of misfolded $A \beta$ for seeding into vulnerable APP mice. The changes in the resulting pathology associated with seeding via synthetic $A \beta$ prepared under slightly different protocols supports the importance of understanding the role of individual components of amyloid seeds in ensuing pathology.

\section{Morphology of seeded pathology}

The seeded pathology from synthetic seeds features pathological morphologies similar to those in other seeding paradigms. Synthetic $A \beta$ injection results in an increase in detected GFAP $[13,16]$. ThioS-positive deposits are found in APP23:Gfap-luc mice injected with synthetic $A \beta 40$ or $A \beta 42$, with and without SDS treatment [16]. In addition, synthetic $A \beta 40$ injections increase overall levels of $A \beta 40$ and $A \beta 42$ in the host brain compared to uninjected controls $[13,16]$. Diffuse or compact plaques can be induced via synthetic $A \beta$ seeding [16]. As the use of synthetic $A \beta$ seeds is refined, it may be possible to more precisely program the type of pathology that forms in the seeded host APP mice.

\section{How does $\mathbf{A} \boldsymbol{\beta}$ seeding compare to prions?}

Amyloid seeding shares several features of prion templating, as both proteins develop altered tertiary structure, leading to self-aggregation in the brain (reviewed in [46-49]). Amyloid pathology can be induced via seeding with human homogenates, but requires a host that expresses human APP transgenes and a relatively direct route of seed administration; intraperitoneal administration has demonstrated some induction of aggregate development, while other peripheral methods have not demonstrated efficacy $[7,8]$. These external routes that have been tested include oral (administration of brain extract onto tongue over the course of 5 days), intravenous (a dilution injected over 10 days maximum), 
intranasal (inhalation twice in each nostril), and intraocular (injection into the vitreous cavity), with concentration and dose combinations differing by route of administration [7]. Conversely, oral routes of transmission are an established route of transmission of prion diseases [50]. Experimentally, prion protein cannot induce prion pathology in mice that do not express PrP (knockouts of Prnp), indicating the role of endogenous PrP in the development of pathology [49, 51, 52]. Although prions cannot replicate in Prnp knockout mice, prion infectivity can survive passage through these mice. Similarly, A $\beta$ seeds from transgenic murine brain homogenate can survive passage through APP-null mice [20].

In terms of structure, there is evidence to support the transition in protein structure of $\mathrm{A} \beta$ monomer from alpha helices to alpha sheets, and then eventually fibrils in the form of beta sheets [53, 54]. These intermediate assemblies may be recognized as different strains of $\mathrm{A} \beta$ with varying seeding abilities. $\operatorname{PrP}^{\mathrm{C}}$ is also largely believed to be composed of alpha helices, while the prion form, $\operatorname{PrP}^{\mathrm{SC}}$, has a greater beta sheet composition [49, 55-57]. These conformational changes drive the self-assembly of these the proteins into higher order structures that produce pathological lesions. The relative titer of $A \beta$ seeds in mouse models or humans, does not appear to be as high as typical prion seeding titers. Prion titers are quantified by measuring dilution of seed and assessing incubation time to death. In hamsters infected with prions the infectivity titer routinely measures out at greater than $10^{7}$, meaning that brain homogenates of an infected animal can be diluted 10 million-fold and still retain sufficient prion seeds to induce disease [58]. In titrating $A \beta$ seeds, the critical measure would be the interval between injection and amyloid deposition since $A \beta$ pathology does not cause obvious clinical signs or death; however, these measurements may be influenced by the location of the injection or the age of the recipient APP model injected (see above). The potency of amyloid seeding is also influenced by the severity of pathology in the donor mouse that is used to produce the $A \beta$ seeds. To compare seeding capability between donor strains, researchers prepared serial dilutions of seed preparations from very old APP23 and APPPS1 mice, and determined the dilutions in which $50 \%$ of the animals showed amyloid deposition $\left(\mathrm{SD}_{50}\right)$; the $\mathrm{SD}_{50}$ was estimated as $10^{3}$ and $10^{2.57}$, respectively [21]. Seeds prepared from old Tg2576 mice could be diluted to $10^{6}$ and retain seeding capability demonstrating $A \beta$ seeding titers comparable to prions [59]. A direct comparison of the relative seeding capacity of these proteins where the levels of misfolded prion and misfolded $A \beta$ are equivalent in the seeding homogenate would be useful.

\section{Future directions}

The influences of the various variables associated with amyloid seeding demonstrate avenues to manipulate amyloid pathology. One of the consistent benefits of $A \beta$ seeding in murine models is the augmentation of $A \beta$ deposition, which accelerates the time-course of experiments. A future goal of seeding studies could be to identify the molecular mechanisms between the interaction of $A \beta$ and tau, the two hallmark protein aggregates of $A D$ pathology. Seeding studies have the potential to explore the relationship between specific types, or strains, of $A \beta$ pathology and the induction of tau pathology and cognitive decline in vivo.

\section{Supplementary Information}

The online version contains supplementary material available at https://doi. org/10.1186/s13024-021-00429-4.

Additional file 1: Table S1. Summary of $A \beta$ seeding studies.

\section{Abbreviations}

AD: Alzheimer's disease; APP: Amyloid precursor protein; A $\beta$ : Amyloid- $\beta$; CAA: Cerebral amyloid angiopathy; CNS: Central nervous system; F: Female; GFAP: Glial fibrillary acidic protein; M: Male; PS1: Presenilin1; ThioS: Thioflavin-

Acknowledgements

We thank Dr. Jada Lewis for support of this effort.

Authors' contributions

BSU, BDM performed literature search. BSU, DRB, BDM wrote and edited the manuscript. All authors read and approved the final manuscript.

\section{Funding}

This work was supported by funding from the National Institutes of Health; grant numbers R01AG049456, RF1AG064914, T32AG061892, R21AG055113, and 1P50AG047266, and by the SantaFe HealthCare Alzheimer's Disease Research Center.

Availability of data and materials

Not applicable.

Ethics approval and consent to participate

Not applicable.

Consent for publication

Not applicable.

Competing interests

The authors declare that they have no competing interests.

Received: 20 October 2020 Accepted: 1 February 2021

Published online: 15 February 2021

References

1. Hyman BT, Phelps CH, Beach TG, Bigio EH, Cairns NJ, Carrillo MC, et al. National Institute on Aging-Alzheimer's association guidelines for the neuropathologic assessment of Alzheimer's disease. Alzheimers Dement. 2012;8:1-13.

2. Jankowsky $\mathrm{J}$, Zheng $H$. Practical considerations for choosing a mouse model of Alzheimer's disease. Mol Neurodegener. 2017;12:89.

3. Liu P, Reichl JH, Rao ER, McNellis BM, Huang ES, Hemmy LS, et al. Quantitative comparison of dense-Core amyloid plaque accumulation in amyloid- $\beta$ protein precursor transgenic mice. J Alzheimers Dis. 2017:56: 743-61. 
4. Kane MD, Lipinski WJ, Callahan MJ, Bian F, Durham RA, Schwarz RD, et al. Evidence for seeding of beta -amyloid by intracerebral infusion of Alzheimer brain extracts in beta -amyloid precursor protein-transgenic mice. J Neurosci. 2000:20:3606-11.

5. Walker LC, Callahan MJ, Bian F, Durham RA, Roher AE, Lipinski WJ. Exogenous induction of cerebral $\beta$-amyloidosis in $\beta$ APP-transgenic mice. Peptides. 2002;23:1241-7.

6. Meyer-Luehmann M, Coomaraswamy J, Bolmont T, Kaeser S, Schaefer C, Kilger $E$, et al. Exogenous induction of cerebral B-Amyloidogenesis is governed by agent and host. Science. 2006;313:1781-4.

7. Eisele YS, Bolmont T, Heikenwalder M, Langer F, Jacobson LH, Yan Z-X, et al. Induction of cerebral $\beta$-amyloidosis: Intracerebral versus systemic $A \beta$ inoculation. Proc Natl Acad Sci U S A. 2009;106:12926-31.

8. Eisele YS, Obermüller U, Heilbronner G, Baumann F, Kaeser SA, Wolburg H, et al. Peripherally applied $A \beta$-containing inoculates induce cerebral $\beta$ amyloidosis. Science. 2010;330:980-2.

9. Watts JC, Giles K, Grillo SK, Lemus A, DeArmond SJ, Prusiner SB. Bioluminescence imaging of Abeta deposition in bigenic mouse models of Alzheimer's disease. Proc Natl Acad Sci U S A. 2011;108:2528-33.

10. Morales R, Duran-Aniotz C, Castilla J, Estrada LD, Soto C. De novo induction of amyloid- $\beta$ deposition in vivo. Mol Psychiatry. 2012;17:1347-53.

11. Langer F, Eisele YS, Fritschi SK, Staufenbiel M, Walker LC, Jucker M. Soluble $A \beta$ seeds are potent inducers of cerebral $\beta$-amyloid deposition. J Neurosci. 2011;31:14488-95.

12. Hamaguchi T, Eisele YS, Varvel NH, Lamb BT, Walker LC, Jucker M. The presence of $A \beta$ seeds, and not age per se, is critical to the initiation of $A \beta$ deposition in the brain. Acta Neuropathol. 2012;123:31-7.

13. Stöhr J, Watts JC, Mensinger ZL, Oehler A, Grillo SK, DeArmond SJ, et al. Purified and synthetic Alzheimer's amyloid beta (AB) prions. Proc Natl Acad Sci U S A. 2012;109:11025-30.

14. Heilbronner G, Eisele YS, Langer F, Kaeser SA, Novotny R, Nagarathinam A, et al. Seeded strain-like transmission of $\beta$-amyloid morphotypes in APP transgenic mice. EMBO Rep. 2013;14:1017-22.

15. Sturchler-Pierrat C, Abramowski D, Duke M, Wiederhold KH, Mistl C, Rothacher $S$, et al. Two amyloid precursor protein transgenic mouse models with Alzheimer disease-like pathology. Proc Natl Acad Sci U S A. 1997;94: 13287-92.

16. Stöhr J, Condello C, Watts JC, Bloch L, Oehler A, Nick M, et al. Distinct synthetic $A \beta$ prion strains producing different amyloid deposits in bigenic mice. Proc Natl Acad Sci U S A. 2014;111:10329-34.

17. Eisele YS, Fritschi SK, Hamaguchi T, Obermüller U, Füger $P$, Skodras A, et al. Multiple factors contribute to the peripheral induction of cerebral $\beta$ amyloidosis. J Neurosci. 2014;34:10264-73.

18. Fritschi SK, Cintron A, Ye L, Mahler J, Bühler A, Baumann F, et al. A $\beta$ seeds resist inactivation by formaldehyde. Acta Neuropathol. 2014;128:477-84.

19. Fritschi SK, Langer F, Kaeser SA, Maia LF, Portelius E, Pinotsi D, et al. Highly potent soluble amyloid- $\beta$ seeds in human Alzheimer brain but not cerebrospinal fluid. Brain. 2014;137:2909-15.

20. Ye L, Fritschi SK, Schelle J, Obermüller U, Degenhardt K, Kaeser SA, et al. Persistence of A $\beta$ seeds in APP null mouse brain. Nat Neurosci. 2015;18: 1559-61.

21. Ye L, Rasmussen J, Kaeser SA, Marzesco A-M, Obermüller U, Mahler J, et al. $A \beta$ seeding potency peaks in the early stages of cerebral $\beta$-amyloidosis. EMBO Rep. 2017;18:1536-44.

22. Ziegler-Waldkirch S, D'Errico P, Sauer J-F, Erny D, Savanthrapadian S, Loreth $D$, et al. Seed-induced $A \beta$ deposition is modulated by microglia under environmental enrichment in a mouse model of Alzheimer's disease. EMBO J. 2018;37:167-82.

23. Geula C, Nagykery N, Wu C-K. Amyloid- $\beta$ deposits in the cerebral cortex of the aged common marmoset (Callithrix jacchus): incidence and chemical composition. Acta Neuropathol. 2002;103:48-58.

24. Maclean CJ, Baker HF, Ridley RM, Mori H. Naturally occurring and experimentally induced $\beta$-amyloid deposits in the brains of marmosets (Callithrix jacchus). J Neural Transm. 2000;107:799-814.

25. Baker HF, Ridley RM, Duchen LW, Crow TJ, Bruton CJ. Evidence for the experimental transmission of cerebral beta-amyloidosis to primates. Int $J$ Exp Pathol. 1993;74:441.

26. Baker H, Ridley R, Duchen L, Crow T, Bruton C. Induction of beta (A4)amyloid in primates by injection of Alzheimer's disease brain homogenate. Comparison with transmission of spongiform encephalopathy. Mol Neurobiol. 1994;8:25-39.
27. Ridley RM, Baker HF, Windle CP, Cummings RM. Very long term studies of the seeding of $\beta$-amyloidosis in primates. J Neural Transm. 2006;113:124351.

28. Kayed R, Dettmer U, Lesné S. Soluble endogenous oligomeric a-synuclein species in neurodegenerative diseases: expression, spreading, and cross-talk. J Parkinsons Dis. 2020;10:791-818.

29. McAllister B, Lacoursiere S, Sutherland R, Mohajerani M. Intracerebral seeding of amyloid- $\beta$ and tau pathology in mice: factors underlying prionlike spreading and comparisons with a-synuclein. Neurosci Biobehav Rev. 2020;112:1-27.

30. Peng C, Trojanowski J, Lee V. Protein transmission in neurodegenerative disease. Nat Rev Neurol. 2020;16:199-212.

31. Chakrabarty P, Jansen-West K, Beccard A, Ceballos-Diaz C, Levites Y, Verbeeck $C$, et al. Massive gliosis induced by interleukin- 6 suppresses Abeta deposition in vivo: evidence against inflammation as a driving force for amyloid deposition. FASEB J. 2010;24:548-59.

32. Dickson T, Vickers J. The morphological phenotype of $\beta$-amyloid plaques and associated neuritic changes in Alzheimer's disease. Neuroscience. 2001; 105:99-107.

33. Xu G, Fromholt SE, Chakrabarty P, Zhu F, Liu X, Pace MC, et al. Diversity in $A \beta$ deposit morphology and secondary proteome insolubility across models of Alzheimer-type amyloidosis. Acta Neuropathol Commun. 2020;8:43.

34. Jankowsky JL, Fadale DJ, Anderson J, Xu GM, Gonzales V, Jenkins NA, et al. Mutant presenilins specifically elevate the levels of the 42 residue $\beta$-amyloid peptide in vivo: evidence for augmentation of a 42 -specific $\gamma$ secretase. Hum Mol Genet. 2004;13:159-70.

35. Walker LC. Prion-like mechanisms in Alzheimer disease. Handb Clin Neurol. 2018:153:303-19.

36. Xu G, Ran Y, Fromholt SE, Fu C, Yachnis AT, Golde TE, et al. Murine Aß overproduction produces diffuse and compact Alzheimer-type amyloid deposits. Acta Neuropathol Commun. 2015;3:72.

37. Cai $H$, Wang $Y$, McCarthy $D$, Wen $H$, Borchelt $D$, Price $D$, et al. BACE1 is the major beta-secretase for generation of Abeta peptides by neurons. Nat Neurosci. 2001;4:233-4.

38. Kimura A, Hata S, Suzuki T. Alternative selection of $\beta$-site APP-cleaving enzyme 1 (BACE1) cleavage sites in amyloid $\beta$-protein precursor (APP) harboring protective and pathogenic mutations within the $A \beta$ sequence. $J$ Biol Chem. 2016;291:24041-53.

39. Trambauer J, Fukumori A, Steiner H. Pathogenic A $\beta$ generation in familial Alzheimer's disease: novel mechanistic insights and therapeutic implications. Curr Opin Neurobiol. 2020;61:73-81.

40. Jarrett JT, Berger EP, Lansbury PT. The carboxy terminus of the Beta. Amyloid protein is critical for the seeding of amyloid formation: implications for the pathogenesis of Alzheimer's disease. Biochemistry. 1993; 32:4693-7.

41. Mucke L, Masliah E, Yu GQ, Mallory M, Rockenstein EM, Tatsuno G, et al. High-level neuronal expression of abeta 1-42 in wild-type human amyloid protein precursor transgenic mice: synaptotoxicity without plaque formation. J Neurosci. 2000:20:4050-8.

42. Thal DR, Rüb U, Schultz C, Sassin I, Ghebremedhin E, Del Tredici K, et al. Sequence of $A \beta$-protein deposition in the human medial temporal lobe. J Neuropathol Exp Neurol. 2000;59:733-48.

43. Hori $Y$, Hashimoto $T$, Nomoto H, Hyman B, Iwatsubo T. Role of Apolipoprotein $E$ in $\beta$-Amyloidogenesis: isoform-specific effects on protofibril to fibril conversion of $a \beta$ in vitro and brain $a \beta$ deposition in vivo. J Biol Chem. 2015;290:15163-74.

44. Dean DN, Das PK, Rana P, Burg F, Levites Y, Morgan SE, et al. Strain-specific fibril propagation by an Aß Dodecamer. Sci Rep. 2017;7:40787.

45. Qiang W, Yau W-M, Lu J-X, Collinge J, Tycko R. Structural variation in amyloid- $\beta$ fibrils from Alzheimer's disease clinical subtypes. Nature. 2017; 541:217-21.

46. Walker LC, Schelle J, Jucker M. The prion-like properties of amyloid- $\beta$ assemblies: implications for Alzheimer's disease. Cold Spring Harb Perspect Med. 2016;6.

47. Will RG, Ironside JW. Sporadic and infectious human prion diseases. Cold Spring Harb Perspect Med. 2017;7.

48. Jucker M, Walker LC. Self-propagation of pathogenic protein aggregates in neurodegenerative diseases. Nature. 2013;501:45-51.

49. Van Ba IA-T, Imberdis T, Perrier V. From prion diseases to prion-like propagation mechanisms of neurodegenerative diseases. Int J Cell Biol. 2013;2013. 
50. Prusiner SB, Cochran SP, Alpers MP. Transmission of Scrapie in hamsters. J Infect Dis. 1985;152:971-8.

51. Büeler H, Aguzzi A, Sailer A, Greiner R-A, Autenried P, Aguet M, et al. Mice devoid of PrP are resistant to scrapie. Cell. 1993;73:1339-47.

52. Prusiner SB, Groth D, Serban A, Koehler R, Foster D, Torchia M, et al. Ablation of the prion protein (PrP) gene in mice prevents scrapie and facilitates production of anti-PrP antibodies. Proc Natl Acad Sci U S A. 1993; 90:10608-12.

53. Chen G, Xu T, Yan Y, Zhou Y, Jiang Y, Melcher K, et al. Amyloid beta: structure, biology and structure-based therapeutic development. Acta Pharmacol Sin. 2017:38:1205-35.

54. Shea D, Hsu C-C, Bi TM, Paranjapye N, Childers MC, Cochran J, et al. a-Sheet secondary structure in amyloid $\beta$-peptide drives aggregation and toxicity in Alzheimer's disease. Proc Natl Acad Sci. 2019;116:8895-900.

55. Huang Z, Gabriel JM, Baldwin MA, Fletterick RJ, Prusiner SB, Cohen FE. Proposed three-dimensional structure for the cellular prion protein. Proc Natl Acad Sci. 1994;91:7139-43.

56. Riek R, Hornemann S, Wider G, Billeter M, Glockshuber R, Wüthrich K. NMR structure of the mouse prion protein domain PrP (121-231). Nature. 1996; 382:180-2.

57. Pan KM, Baldwin M, Nguyen J, Gasset M, Serban A, Groth D, et al. Conversion of alpha-helices into beta-sheets features in the formation of the scrapie prion proteins. Proc Natl Acad Sci U S A. 1993;90:10962-6.

58. Bolton DC, McKinley MP, Prusiner SB. Identification of a protein that purifies with the scrapie prion. Science. 1982;218:1309-11.

59. Morales R, Bravo-Alegria J, Duran-Aniotz C, Soto C. Titration of biologically active amyloid- $\beta$ seeds in a transgenic mouse model of Alzheimer's disease. Sci Rep. 2015;5:9349.

\section{Publisher's Note}

Springer Nature remains neutral with regard to jurisdictional claims in published maps and institutional affiliations.

Ready to submit your research? Choose BMC and benefit from:

- fast, convenient online submission

- thorough peer review by experienced researchers in your field

- rapid publication on acceptance

- support for research data, including large and complex data types

- gold Open Access which fosters wider collaboration and increased citations

- maximum visibility for your research: over $100 \mathrm{M}$ website views per year

At $\mathrm{BMC}$, research is always in progress.

Learn more biomedcentral.com/submissions 